\title{
Rudali: A Critique of an Exploitative, Socio-Economic and Religious System
}

\author{
Dr. B. Vijaya \\ Asst. Professor, Department of English, University College of Arts and Social Sciences, \\ Osmania University. Email: gangavathvijaya@yahoo.in
}

\begin{abstract}
Mahasweta Devi, one of the indomitable fighters who fought her last battle at the age of 90 in 2016, is a voice for the voiceless and a remarkable writer-activist India has ever seen. She is a Bengali novelist, short story writer, playwright, essayist, columnist, editor and above all a socio-cultural activist who has relentlessly worked for decades highlighting the problems of the rural poor and tribals. The tribals and their history have become an integral part of Mahasweta Devi's life and mission. Her empathy for the rural poor and tribals coupled with her intense anger against their exploitation has made her a committed activist-writer. Mahasweta Devi believes that every writer is answerable to the people and therefore it is his/her responsibility to create awareness among the people about the misery of the least privileged, the dispossessed.
\end{abstract}

Keywords: Mahasweta Devi, social activism, poverty, injustice

Mahasweta Devi, one of the indomitable fighters who fought her last battle at the age of 90 in 2016, is a voice for the voiceless and a remarkable writer-activist India has ever seen. She is a Bengali novelist, short story writer, playwright, essayist, columnist, editor and above all a sociocultural activist who has relentlessly worked for decades highlighting the problems of the rural poor and tribals. The tribals and their history have become an integral part of Mahasweta Devi's life and mission. Her empathy for the rural poor and tribals coupled with her intense anger against their exploitation has made her a committed activist- writer. Mahasweta Devi believes that every writer is answerable to the people and therefore it is his/her responsibility to create awareness among the people about the misery of the least privileged, the dispossessed.

The quality of Mahasweta's literary works as well as the nature of her corresponding social action makes her a distinguished writer not only among her Indian counterparts but also among the most illustrious writers and intellectuals the world over. More than two hundred years of tribal struggles for human dignity inform her fictional and non-fictional works. Thus, humanism forms the most important ethic of Mahasweta's ouevre. She faithfully documents the heroic grandeur of the indomitable tribal will with artistry and passion which make her work a truly inspiring saga. By means of subversion, she places the dauntless struggle of the exploited people on top of her fictional agenda. Hence, M. Asaduddin points out, "she presents the rare combination of an activist and a writer who has been leading a spirited crusade against social injustice meted out to disenfranchised and the dispossessed."(34).

(c) AesthetixMS 2016. This Open Access article is published under a Creative Commons Attribution Non-Commercial 4.0 International License (http://creativecommons.org/licenses/by-nc/4.o/), which permits non-commercial re-use, distribution, and reproduction in any medium, provided the original work is properly cited. For citation use the DOI. For commercial re-use, please contact aesthetixms@gmail.com. 
History and myths characterize the work of Mahasweta. She creates myths out of historical events and personalities. In the first place her works are deeply rooted in history. During the $19^{\text {th }}$ century, a good number of tribal revolts took place in India, particularly in Bihar and West Bengal. The tribals revolted against the British rulers, the landlords, the money-lenders and other exploiters as they destroyed the forests, the sanctuary of the tribals. Research and reliance on the oral tradition of the tribals are two significant modes of Mahasweta's creative writing. She believes that the policies of the Indian government since independence have been oriented toward perpetuating the legacy of the earlier colonial masters in dispossessing the tribals and their land. As she says, the big projects involve exploiting the landless poor and the tribal communities, consequently the evicted tribals are on the increase "becoming rootless and swelling the number of migrant workers." (Hindustan Times, 18)

Mahasweta Devi is the foremost living chronicler of tribal lives in Bengal. She spent nearly 30 years her life by living and working with the tribals of West Bengal and the southeast Bihar as a political anthropologist, investigative journalist and editor of various journals like "Bortika" (torch). In an interview with Minoli Salgado, she says that in the tribal people she has found "an endless source of ingredients for writing."

The sociologists, anthropologists and social activists agree with the opinion that even now the tribals are not taken appropriate care by the ruling classes. They face multiple problems not only from the privileged sections but also from the protecting agencies like police, the constitution and the law. They are denied of all their rights. Talking about the pitiable situation of the tribals, Sachi Arya says:

'Denial' is the term that pithily descries the lot of the tribals - an all pervasive term, reflective of gross injustice and reduction to a sub-human existence. And the saddest thing is that all this has happened and is happening in the name of principles claiming authority from the constitution and the law.

There is no point of intersection between the tribals and the mainstream where they can be treated as equals. In an interview with Gayatri Chakravorty Spivak, Mahasweta Devi says: "The mainstream and the tribal cultures run parallel; they do not have a meeting point." The subordination of tribal people literally lies in the ideas and motives constructed by the dominant group. Injustice is done to them by the dominant group because of the images which already set in their minds about tribals. Their ignorance, illiteracy, lack of retaliation or protest encourages the dominant sections to create and perpetuate these images. Kumkum Yadav observes that the dominant patterns of representation are "constructed on the basis of socially and structurally dominant values which in turn produced and reproduced through the same set of dominant representations."(158)

Mahasweta uses myths in her stories to bring out the hidden reality. She writes not for the sake of writing alone but for the sake of action. She serves as a mediator between the two worlds separated by a time gap of thousands of years as it were and yet living side by side.

Before critically evaluating the novella on the selected title of the article, it is in place to know a brief outline of the story. Sanichari, the protagonist in Rudali comes from ganju caste of tribals. Like the lives of other villagers her life too was one of unredeeming penury. She was the younger daughter-in-law in a ganju family and her mother-in-law always accused her of bad destiny that was full of sorrow and suffering as she was born on an 'inauspicious Saturday.'(54) Sanichari did not cry at her mother in-law's death as she had no time. As her husband and brother were in jail because of Ramavatar Singh, a landlord and moneylender, she 
had to perform the funeral rites herself that night itself in the pouring rain, otherwise she had to bear the cost of delay and for keeping the corpse in the house overnight. The old woman had died of hunger and "there wasn't even a cupful of grain in the house."(55) So, Sanichari had to run from house to house in the pouring rain and finish the funeral rites. Therefore she hardly had any time to cry for her mother-in-law. Further, the old woman gave so much trouble to Sanichari that even if she had forced herself to cry, no tears would come out. Subsequently all her relatives including her husband die of hunger.

Her only son Budhua, a six year old boy, survives with Sanichari and she works hard to bring him up by splitting wood, gathering fodder for the cows and working in the fields during the harvest season. She makes the ritual offering to her dead husband and spends a precious rupee and a quarter which Budhua offers as 'Pinda.'(57) But Mohanlal, the priest was not happy and satisfied with the ritual and Sanichari was forced to borrow Rs.2o from Ramavatar Singh, the landlord, who makes her lay her thumb impression on a document which says that "She would repay Rs.5o through bonded labour on his fields over next 5 years." (57). Sanichari is about to cry but is interrupted by Dulan Gangu, the only voice in their community, who criticizes, accuses and condemns the upper classes and highlights their moral degradation, corruption, greed and hypocrisy.

People talk ill of her in the village as she did not weep even when her husband died, but she would not heed their comments. She knew that she would not be able to repay her debt to Ramavatar Singh. When Ramavatar Singh's uncle was on his death-bed many visitors came to see him and the room was filled with them. Sanichari seizes this opportunity and loudly pleads from outside the door, "you who are benefactor of the poor! This poor woman begs you to reward the service she did you today! Please wipe out the debt due! Write it out as repaid! (58) And her bond of debt was wiped off for which Ramavatar Singh faced a lot of criticism from other Jotedars and Mahajans. Her hope in Badhua also vanishes when he dies leaving behind his son. "Sanichari got home to find her son dead and her daughter-in-law gone. The baby was crying in the room."(61) With the child in her arms, she cremates her son Badhua and does not cry at his funeral. She takes care of her grandson, Haroa. She finds the job of repairing the government railway line. Therefore, Dulan asks her to shift her hut into their yard. Slowly she becomes normal and brings up Haroa, her grandson as best as she can.

When Haroa was 14 year old, she puts him to work in Lachman Singh's shop in the market place. But after a few days Haroa also runs away. While searching for her grandson, she meets Bhikni, her childhood playmate. They sit under a Peepul tree and share their sad tales. And from that day Bhikni and Sanichari live together and for some days they eat with Bhikni's money. Soon they hear that Bhairab Singh has been murdered. Such things are common in rich families for property and at his death bed Lachman Singh sheds crocodile tears and reminds the Bairab Singh's sons that, "Our duty now is to make sure that Chacha receives all due honour by way of funeral rites."(68) Hence Dulan takes a chance to help Sanichari and Bhikni and he says:

In rich families the son kills the mother, the mother the son. Forget about who killed him. Amongst us, when someone dies, we all mourn. Amongst the rich, family members are too busy trying to find the keys to the safe. They forget all about tears. Our malik has ordered a fancy funeral. The funeral procession will be tomorrow afternoon. They'll be no good. The two of you go, wail cry, accompany the corpse. You'll get Money, rice. On the day of kriya ceremony you'll get clothes and food. (70)

Sanichari is very uncomfortable to do that job as she did not cry even when her kith and kin died. "Sanichari felt an earthquake within. She exploded. Cry? Me? Don't you know" I can't 
shed tears. These two eyes of mine are scorched?"(70) Dulan convinces her and sends both of them as rudalis to wail over the corpse of Bhairab Singh. This is the beginning of her work as rudali. Sanichari and Bhikni wailed loudly and started singing songs in praise of Bairab Singh and "Sanichari thought that perhaps her tears had been reserved for the time when she would have to feed herself by selling them." ${ }_{72}$ ) Now it has become a profession for Sanichari and Bhikni to wail over the corpses and here Mahasweta indicts the society for commoditizing a poor woman's tears. Shanichari has to sell her tears at the funerals of the rich for her living. Therefore, the central theme of this story is 'survival.'

At the end of the novella, Sanichari evolves into a strong, confident and empowered tribal woman, surviving victoriously. This transformation in her is caused by Dulan, a member of her tribe. In this context Mahasweta Devi blasts the popular misconception about the Indian village that it is traditional and peaceful by projecting the power structures that govern the village life and also by exposing the corrupt and cruel ways of the socially and economically dominant class like that of Ramavatar Singh. For Sanichari, it is not so much the question of noble birth or fate that bothers, but it is their pitiable economic condition.

Mahasweta Devi's fiction, essays, plays, journalistic writings and her activism could be viewed as a gesture of protest, a resistance to the dominant power structures in India. She deals with the following themes in her writings:

Privileged communities vs. underprivileged communities (caste inequalities)

The rich vs. the dispossessed (class contradictions)

Male vs. Female (gender discrimination)

Mahasweta Devi takes the side of the marginalized in the above binaries and records their travails. This concern for the downtrodden is born out of her conviction that Independence has not brought any tangible change in their lives and, if anything, the exploitative methods of ruling classes have made them more miserable. She observes:

Our leaders made no special plans for the people living below poverty line or for women who do not know what human rights are. Instead of tackling these basic problems they made conditions worse with misguided policies. They have done more injury and injustice to our people than the British. (The Hindu: Literary Review)

It is with such a mission of fighting for the amelioration of the hardships of the underprivileged that Mahasweta Devi took to writing. For her, social activism and documenting the harsh realities in the form of fiction are inseparable. Every personal event in Sanichari's life is interwoven with the exploitative system. For instance, her husband dies of cholera after drinking the contaminated milk offered to the idol of Shiva by the so called rich people. Sanichari is forced to pay twice to the local priest, who is also the family priest of Ramavatar Singh, for the ritual. Hence, she is indebted to Ramavatar Singh, the heartless landlord. He had all the young dushads and ganju's of the village locked up because of his anger at the piliferage of some wheat. Therefore, Ramavatar is the representative of an exploitative, dehumanized system that controls the lives of the subalterns like Sanichari.

Sanichari's son Budhua, dies of tuberculosis while working with Lachman Singh, son of Ramavatar. When her grandson grows, she takes him to Lachman Singh for a job because there is no other source of employment for them and their lives and minds are controlled by the exploitative socio-economic and religious environment. For the rich oppression is hereditary. The exploiter takes it as his birth right to victimise the oppressed. Hence the oppression becomes 
hereditary for both the exploiter and the exploited. Of course, postcolonial theory dismantles all these hegemonic concepts of the ruler and the ruled; Centre and the Margin etc.

The entire novella is a critique of the socio-economic and religious system. Portraying the acute poverty of the villagers and the ways in which they are exploited because of their illiteracy, ignorance, superstitions and above all the unbridled power of the privileged classes makes Mahasweta Devi a powerful committed writer. The story of Sanichari best illustrates the point. She borrows a meager sum of Rs.20/- for her husband's samskara (a rite for a dead man) and ends paying Rs.50/- through the exploitative evil Indian system of bonded labour. In contrast her masters spend thousands of rupees lavishly and carelessly for the same rite for their family members without any sense of guilt of squandering money.

To continue to exercise the power over the underprivileged, the so called malik-mahajans instill in the ignorant villagers superstitions and the irrational fear of God. To propitiate and appease God's and Goddesses, the poor borrow money from the landlords and become bonded slaves to them. Throughout the novella, religion is depicted as an instrument of suppression to turn the poor into slaves. Hence, the charectars in Mahasweta Devi's writings are those whom she had encountered in real life, namely, the migrant workers, the lowest of the society, landless labourers, poor abandoned women, tribals with no rights and those who exploited abused and suppressed them. She is the voice for the voiceless, the sualterns.

Besides her submissive and exploited characters like Sanichari, Mahasweta Devi also introduces an empowering character like Dulan, who acts as a help and adviser to the tribals by educating and enlightening them about their rights etc. Knowledge and information are powerful tools for people like Dulan. He in fact appreciates the Rudalis (professional mourners) since he considers them as the organized labour. With Dulan's encouragement and strong support Sanichari, emerges as a confident and empowered woman at the end of the novella thereby proving that subalterns can be empowered through education and organization.

\section{Works cited}

Asaduddin, M. “Of Rape and Marginalization.” The Book Review 26:11 (November, 2002). Print.

Arya, Sachi. Tribal Activism. Jaipur and New Delhi: Rawat Publications, 1991. Print.

Chakraborty, Urmila. "Art as Protest: Social Commitment in the Novels of Mahasweta Devi”, Indian Women Novelists: Set III: Vol7. Dhawan R.K.(Ed), New Delhi: Prestige Books, 1995. Print.

Chary, A. Jaganmohana “Deconstructing History: A Study of Mahaswetha's Imaginary Maps.” Revaluations 3:1 Summer, 1997. Print.

Chatterjee, Enakshi. “In Focus.” Indian Review of Books. 6:9 (16 June-July, 1997)Collu, Gabrielle. “Adivasis and the Myth of Independence: Mahaswetha Devi's Douloti, the Bountiful." Ariel 30:1 (January, 1999).Print.

Devy, G.N. "Confrontation with Society." The Hindu (Sunday, 1 August, 1993)

Devi. Mahaswetha. Asaduddin, M. “Of Rape and Marginalization,” The Book Review $26^{\text {th }}$ November, 2002. Print.

-----. “Chronicles of the Oppressed.” Kakatiya Journal of English Studies. 1998. 
Spivak, Gayatri Chakravorty. “Draupadi, translator’s foreword.” Breast Stories. Calcutta: Seagull Books, 1998. Print.

.... “More on Power/Knowledge." Outside In The Teaching Machine. London \& Newyork: Routledge, 1993. Print.

-----. “Increasing Awareness." The Hindu (Sunday, August 3, 1997).Print.

Guha, Ranajit. Et al., Subaltern Studies - II. Delhi: OUP, 1973. Print.

-----. Subaltern Studies - V. Delhi: OUP, 1985. Print.

-----. Subaltern Studies - VI. Delhi: OUP, 1989. Print.

Karlekar, Malavika. "Book Review of Mother of 1084, Rudali: From Fiction to Performance, Five Plays, Breast Stories.” Indian Journal of Gender Studies. 5:1, January-June, 1998. Print.

Kaur, Iqbal. Gender and Literature. Delhi: B.R. Publishing Corporation, 1992. Print.

Krishnaraj, Maithreyi. "Motherhood: Power and Powerlessness." Indian Women, Myth and Reality. Sangam Books. Print.

Rao, Mallikarjun.P. \& Rao, Damodar.K. “Editorial.” Kakatiya Journal of English Studies. Vol.18.1998. Print.

Sachidanandan, “The Tribal Situation in Bihar." The Tribal Situation in India. ed. Dr. K.S. Singh, Motilal Banaras Das. New Delhi, 1972. Print.

Salgado, Minoli. “Tribal Stories, Scribal Worlds: Mahasweta Devi and the Unreliable Translator," The Journal of Commonwealth Literature 35:1, 2000, 131. Print.

Spivak, Gayatri Chakravorty. “A Literary Representation of the Subaltern: Mahaswetha Devi's 'Stanadayini', Subaltern Studies V: Writings on South Asian History and Society, ed. Ranajith Guha, Delhi: Oxford University Press, 1990. Print.

-----. "Deconstructing Historiography." In Other Words: Essays in Cultural Politics. New York \& London: Methuen. 1987. Print.

Tharu, Susie \& K. Lalitha. Women Writing in India. New York: The Feminist Press, 1983.

Yadav, Kumkum. Tribals in Indian Narratives. Shimla: Indian Institute of Advanced Study, 2003. Print.

-----“Tribal women in Modern Indian Writing.” Tribals in Indian Narratives. Shimla:

Indian Institute of Advanced Study, 2003. Print.

Dr. B. Vijaya is Asst. Professor, Department of English, University College of Arts and Social Sciences, Osmania University \& Asst. Director, UGC, HRDC, Osmania University. Email: Email: gangavathvijaya@yahoo.in 